\title{
The Association of Research Libraries
}

Detroit, Michigan

July 3, 1965

HE SIXTY-SLXTH MEETING of the Association of Research Libraries opened at 2 P.M. with a program session at the McGregor Conference Center of Wayne State University. Edward G. Freehafer, director of the New York public library and chairman of ARL, presided. He introduced William S. Dix (Princeton) to report on the Shared Cataloging Program, "a vehicle now happily orbiting around Capitol Hill."

This program was given top priority over a year ago, because a major problem of research libraries is to have more books cataloged more promptly than is now possible through the Library of Congress, Mr. Dix, chairman of the Shared Cataloging Committee, said. ARL, in a "unilateral decision" and after considering various alternatives, decided that the answer was a Centralized Cataloging Program, which should be supported by the federal government and which should be carried out by LC. In testifying on the Higher Education Act of 1965 in both the House and the Senate, ARL representatives advocated and LC supported an amendment that would authorize an appropriation to the Department of Health, Education and Welfare ( $\$ 5$ million for the first year) for transfer by the Commissioner of Education to LC to finance the acquisition of more materials of research value and to provide for prompt cataloging (within three or four weeks, especially in foreign languages, of receipt of the books). This suggestion was sympathetically received in both houses. It is now embodied in Part C, Section 231, of Title II of H.R. 9567, which has been reported favorably by the Committee on Education and Labor; Senator Wayne Morse, chairman of the Subcommittee on Education, with other members of the subcommittee joining him, introduced a similar amendment to S. 600 , the Senate Higher Education Bill, which is now being considered by the subcommittee in executive session.

Some forty thousand cards, representing the cataloging production of nine libraries during March, have been received for use in the study of shared cataloging being made for ARL by John Dawson (University of Delaware), Mr. Dix reported. They will provide the basis for an analysis of the types of cataloging provided for various categories of publications.

Benjamin E. Powell (Duke University), chairman of the Committee on the Center for Research Libraries, which was established at the invitation of the center to consider its program, organizational structure, and funding, reported on its recommendations, which had been discussed with the librarian of Congress and the assistant librarian in advance and, insofar as they affected LC, had been approved in principle. The committee studied the report of the survey of the center made by Stephen A. McCarthy (Cornell University) and Raynard C. Swank (California, Berkeley), and the committee's conclusions were "very preliminary" and highly selective, Mr. Powell emphasized.

The Center for Research Libraries, which was created in 1949 as the Midwest InterLibrary Center, in recent years has assumed some of the characteristics of a national agency although the bases of its support have remained primarily regional. Its name was therefore changed to reflect this increased scope.

"The problems associated with acquisition, preservation, and dissemination of knowledge, which become more complex every year, are completely familiar to ARL members," Mr. Powell said. "These problems have grown out of the increase in knowledge and the expanding rate of publications; the extension of research interests to include geographic and subject areas of little concern to scholarship prior to the twentieth century; the increase in research and in the number of researchers; and the increase in the urgency of access to information. Included also is the problem of how to preserve the materials that are now deteriorating in libraries as well as how best to adapt available machinery and electronic equipment to the needs of research libraries. 
Solution of these and other problems will require our best efforts and the highest possible degree of cooperation among all research libraries. ... .

"If the Library of Congress increases substantially its coverage of the world's literature, and catalogs these materials promptly, its own resources will be strengthened and research libraries generally will be greatly assisted. Then, if these research libraries can agree to share use and ownership of the masses of material that are likely to be little used, including documents, newspapers, and serials of developing countries and retrospective printed records of countries not hitherto included in the teaching and research programs of most universities, the average ARL library will be relieved of a heavy burden and the scope of material available to it increased immeasurably. It is the belief of the committee," Mr. Powell said, "that solution of many of the multivaried problems facing research libraries lies in this direction and that a center, directed by the research libraries of the country, that can extend such services .... as are now provided through the Center for Research Libraries, offers advantages that should be explored."

The committee gave attention to five areas and suggested a division of responsibility between the center and LC. First, under "Resources and Bibliographic Control," the committee felt that LC should enlarge the scope of its acquisitions and provide prompt, centralized cataloging (as Part C, Section 231, of Title II of H.R. 9567, described above, envisions). It should also obtain for the center, from countries lacking an organized book trade, a second copy of research materials, which would serve as a loan copy for the scholarly community. The center should develop collections of currently published materialsretrospective collecting is not anticipatedunder good control and should provide speedy, low-cost access to them. It could also reprint or reproduce various types of publications, expand its foreign newspaper microfilm program, and possibly take over such projects as NYPL's Foreign Gazettes Microfilm Program.

Second, a national preservation program, which should be supported by federal funds, should be undertaken by LC be- cause in its extensive collection are many of the materials that need to be preserved for the research community. The committee felt that this program should be based on the recommendations that ARL's Committee on Preservation presented at the 1965 midwinter meeting and that were adopted in principle. The center could give its attention to assuring that current publications are printed on permanent/durable paper and to testing papers used.

Third, in regard to automation, there was "no question but that the Library of Congress should be responsible for developing the techniques and standards required for the automation of bibliographic information." The center might test and evaluate.

Fourth, the center should administer the Farmington Plan, and it should consider programs to collect social science machinereadable data now being produced by government, business, and universities and to provide bibliographic control over these data.

Fifth, in regard to funding the center, the committee felt that major financial support "for any broad program" for CRL had to come from the federal government, with LC, HEW, and the National Science Foundation and the National Foundation on the Arts and the Humanities being possible sources. Nongovernment foundation assistance, as well as support either by member libraries or by higher ARL dues to be passed on to the center "as the operating arm of the association," was also envisioned. No definite pattern of funding or organization was recommended.

Discussion brought out the fact that the committee did not think of the center as a federal agency or as a "second" national library, but some found it hard to envision continuing and assured federal support without an official link, for example, as a branch of LC. One participant thought that it was rather arrogant to divide up functions between the center and LC when ARL does not even have an official link with the center, but Mr. Powell stressed that the allocations were for discussion purposes only, and others felt that CRL could render a national service, finding its role in relation to LC. The interest of ARL in the development of such a program was affirmed by vote. 
"Effective Distribution of Non-GPO Publications" was discussed by Clifton Brock (University of North Carolina). Basing his talk on his article "Implementing the Depository Law," published in LJ, April 15, Mr. Brock held that, despite major improvements in the depository system accomplished since the passage of the 1962 act, non-GPO publications are not reaching the depository libraries, and he expressed doubt that they ever will in substantial numbers as the law is presently written. There are 340 "departmental plants" and 294 "field plants" producing publications, he said, and only a small portion of them reach libraries through a "chaotic variety of time-consuming, expensive, and problematical acquisition methods." Much valuable material is thus produced outside the regular channels to depository libraries. The issuing agencies can declare such materials "for official use only," or for "strictly administrative or operational purposes which have no public interest or educational value," or they may be classified for reasons of national security. Another deterrent to distribution is the fact that the issuing agencies, rather than the Superintendent of Documents, have to bear the cost of depository copies of non-GPO publications. As a solution, Mr. Brock proposed that one copy of each non-GPO publication, except for classified and strictly internal administrative documents, be required to be sent to the Superintendent of Documents, who could in turn, if so directed, send to depository libraries microfacsimile copies of those centrally determined to have educational and informational value. The Monthly Catalog would list these non-GPO publications at some increase in the size and cost of the Catalog and the microfacsimiles would also increase the cost to the Superintendent of Documents, but this cost, he held would be small in proportion to the value of having these publications available throughout the country.

The afternoon session closed with reports from the three national libraries. Scott Adams (National Library of Medicine) spoke of the Senate hearings on the Medical Library Assistance Act of 1965 at which Richard Logsdon (Columbia University) presented testimony for ARL; alleged conflicts between this bill and Title II of the Higher Education Bill are gradually being resolved. He also reported on HEW's study of the effects of drugs on man, in which NLM will have responsibility for the analysis, through MEDLARS, of chemical compounds and their effects on man; the 100th anniversary of John Shaw Billings' coming to NLM's predecessor, the Surgeon General's Office; work being done on the history of medicine; and NLM's "aggressive" program to acquire manuscripts and recordings - oral history. NLM is now oneand-a-half years deep in programing for cataloging, he said, and expects that systems work and programing will be completed by September, with production to begin by January 1966. It is expected that a biweekly list of current acquisitions will be produced, that it will be cumulated quarterly and annually, and that it will serve as the basis of the annual catalog now produced by LC by the shingling method. GRACE (Graphic Arts Composing Equipment), which produces upper and lower case and can compose a page in one minute, is being used. No decision has been made yet about distributing catalog cards, but they probably will be distributed. The decentralization of the MEDLARS system has begun; Brad Rogers, who has Honeywell equipment, is using the output to supply medical subject headings to the University of Colorado medical school and a contract has been made with UCLA for reprograming for use on IBM equipment. In June, NLM's Board of Regents approved the next regional center- "in the Midwest" -and 25-30 other universities have applied for mechanized research capability.

Foster E. Mohrhardt (National Agricultural Library) reported on the publication of $A B L E$ (Agricultural and Biological Literature Exploitation), a systems study of NAL and its users; the Pesticides Documentation Center, which is NAL's responsibility; the publication, over a period of three years, of the dictionary catalog of NAL, 1862-1965, in sixty-eight volumes, which will sell for $\$ 952$; and a study to see how a mechanized system can help the land-grant colleges. The plans for the new NAL building at Beltsville, to cost $\$ 7$ million, have been returned by the Fine Arts Commission "with warm approval for great architectural achievement," Mr. Mohrhardt said.

After summarizing Congressional action 
on appropriations for LC, progress toward a third library building to be named for James Madison, and some of the projects being handled by computer, such as card division accounts, printing the indexes to the Presidential papers, and the automatic typesetting of the seventh edition of the subject headings list, librarian of Congress Mumford reported on automation at LC, characterizing the year as an extremely active one and one of progress. It took several months to build a talented information systems specialist staff of five professionals and two clerical assistants, he said in describing each member. In addition, a toplevel internal committee, which the librarian himself heads, gives attention to program and policy matters; LC's six special recruits have been assigned to ISS to analyze present LC operations; and a task force of a cataloger and a reference librarian is working with the supervisory programer and and systems analyst on machine-readable catalog records.

The ISS staff has concentrated on two tasks: the development of specifications for automating LC's bibliographic operations and of a standardized format for machinereadable catalog records. The picture of an automated LC given in the King survey team report, Automation and the Library of Congress, is still the best picture and will continue to be used as a guide until its premises are proved untenable, Mr. Mumford said. Work has been directed toward drawing a more precise picture of what LC wants to do, what an automated library will look like, how we can accomplish transition to it, and what it will cost. The detailed analysis of operations, begun in February, includes flowcharting operations, analyzing files and catalogs, interviewing staff, and the like. Consultant help will be required to complete this analysis. In fiscal 1967, a system to meet requirements will be designed, and the next step will be to implement parts of the system.

Of basic significance, especially to librarians, are the data that would be handled by the system. At the conference on machine-readable catalog copy held at LC on January 11, the feasibility of distributing such copy as punched cards, magnetic tape, and punched paper was discussed. But first agreement must be reached on what the record will be, both as to bibliographic content and machine format. The task force under the direction of the supervisory programer is designing a format, and a 110page preliminary report on it for discussion within LC has been completed. It pinpoints many problems that must be solved before further steps can be taken. After review in LC, this report-and others to be issuedwill be made available to the library community for comment, the librarian said.

LC's approach is somewhat different from that of Lawrence F. Buckland of Inforonics, Inc., which was outlined in The Recording of Library of Congress Bibliographical Data in Machine Form. His approach was that catalog card data could be input by formatting so that certain kinds of information are always in specified locations. LC believes that bibliographical data are so diverse and complex that almost every item has to be tagged specifically and that this approach will result in more accurate keypunching than the positional approach. LC's proposed record, however, includes fixed fields to control certain items for quick searching and variable fields for bibliographic data. Thus the catalog information can be as long or as short as the book warrants.

The librarian referred to work being done on the "California List" and to LC's hope that, with foundation support, it will be able to study problems involved in distributing machine-readable catalog records and to establish in LC an information center on automation projects of library interest. In closing he stressed once again the library's commitment to automation and the hope that both the association and its individual members would give LC support in this area.

The program meeting then adjourned for a social hour and dinner. ARL reconvened for its business session at 7:30 P.M., with Mr. Freehafer again in the chair. The evening was devoted chiefly to committee reports.

Gordon Williams (CRL) gave a "nonreport" on the Automation Committee, because Mr. Mumford had covered much of the ground. David Kaser (Joint University Libraries, Nashville) reported for the Committee on the Revision of the Cataloging Code, saying, in essence, that no library will be able to adopt the new code in toto. It would be too expensive. Most will prob- 
ably use the new rules in establishing new headings and will accept LC cards, which will follow the new rules when new headings need to be established but will not change established entries.

John H. Moriarty (Purdue University) presented an interim report of three pages of text and twenty-eight charts on "Growth In ARL Libraries, 1950-1980." From the figures reported by fifty-eight libraries (not including LC) eight "composite" libraries were represented, and volumes held, volumes acquired, and total library expenditures were shown and projected to 1980 . The average "composite," for example, held just under 900,000 volumes in 1950-51, while in 1963-64 this figure had risen to $1,490,000$ volumes, indicating that the fiftyeight libraries held a total of 86.4 million volumes. The projected size of the average collection in 1980 would be $2,860,000$ volumes, but Mr. Moriarty said that a more realistic figure would be $3,750,000$ volumes. A full report is expected late in the summer and will be mailed to ARL members.

John Lorenz (director of the Division of Library Services and Educational Facilities, HEW) described the reorganization of the Office of Education, especially as it affects library services, into four bureaus corresponding to levels of education: elementary and secondary education; higher education; adult and vocational education, including educational TV and the former Library Services Branch; and a bureau of research. In addition, a national center for educational statistics was created.

William N. Locke (Massachusetts Institute of Technology) reported on Project Intrex and a five-week planning conference; Mr. Logsdon described the status of the Medical Library Assistance Act of 1965; Stephen McCarthy discussed the problem of overhead on government research projects and how libraries could get a fair percentage; and a number of committee chairmen or their representatives filed reports ranging in coverage from the Farmington Plan to the National Union Catalog of Manuscript Collections.

The Executive Secretary, James E. Skipper, reported, among other things, on the Systems Development Corporation's study for COSATI of the structuring of a national library information system, on legislation, and on the fact that he will represent ARL at the Helsinki meeting of IFLA. The chair- man reported that the Board of Directors had approved a special fund, not to exceed $\$ 1,000$, for use of the ALA Washington Office on matters of mutual interest to ARL and ALA. At the Executive Secretary's request, a visiting committee to survey the secretariat has been authorized. The Board also voted ARL's thanks to Professor Julian Levi (University of Chicago) for his assistance to the association; it approved the exchange of information when the ARL and the Association of College and Research Libraries have counterpart committees; and it recommended a change in the by-laws to establish the officers of ARL as an executive committee empowered to act between meetings of the Board and the membership, authority that is especially important when legislative developments require prompt action.

After a vote of thanks to Wayne State University for the excellent arrangements for the conference, the sixty-sixth meeting adjourned. ARL will meet next in Chicago, immediately preceding the ALA Midwinter conference.-Elizabeth E. Hamer.

\section{STUDENT LIBRARY COMMITTEES}

(Continued from page 494)

while or not. The librarian and the student members of the committee are the deciding factors in this situation. A student library committee can be very successful and helpful to the librarian and the library staff one year and fail the following year. If there is no continuity of members on the committee, it can turn out to be an abysmal failure. It appears, however, that the trend over a long period of time has been to find out student opinion and work with students in ways other than through a student library committee.

\footnotetext{
IN THE WINTER OF 1965 a Student Library Committee was established at Oakland University, Rochester, Mich. This committee would like to know of similar groups in the United States and effect they have in gearing university libraries to the needs of students and faculty. Responses should be sent to George M. Bailey, executive secretary, ACRL, 50 E. Huron St., Chicago.
} 
SUMMARY OF COLLEGE AND UNIVERSITY LIBRARY STATISTICS: AGGREGATE UNITED STATES, 1959/60-1963/64

Prepared by Theodore Samore, College and University Library Specialist Library Services Branch, U.S. Office of Education

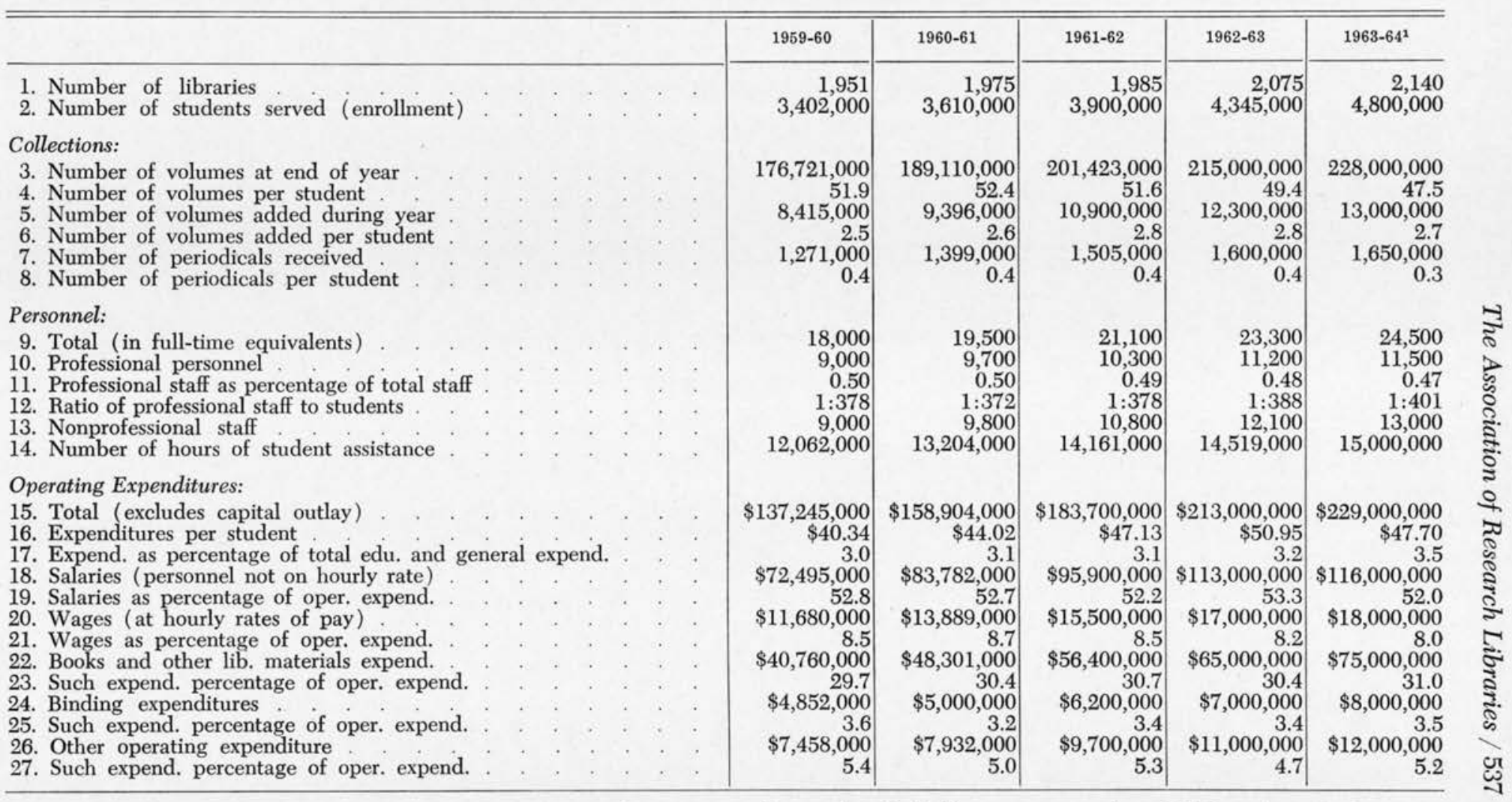

${ }^{1}$ Estimated. When completed data for $1963-64$ will represent a much more exact picture of academic library resources since definitions of certain key terms was clarified and strengthened. For details see the Introduction to Library Statistics of Colleges and Universities, 1963-64. Institutional Data. (OE 15023-64) 


\title{
University Libraries Section Bylaws
}

\author{
(AS AMENDED JULY 1965)
}

\section{Article I. Name}

The name of the Section shall be University Libraries Section.

\section{Article II. Object}

The primary object of the Section shall be to advance university librarianship, university library service, and the development of university libraries. A university is defined as an institution of higher learning which offers programs leading to the degree of doctor of philosophy or its equivalent.

\section{Article III. Membership}

Any member of the Association of College and Research Libraries may elect membership in this Section.

\section{Article IV. Meetings}

An annual meeting of the Section shall be held at the time and place of the annual conference of the American Library Association.

\section{Article V. Officers}

The officers of this Section shall be a chairman, a vice-chairman (chairman elect), and a secretary. The chairman shall serve for one year. The chairman elect shall serve for one year as vice-chairman; at its expiration, or upon the occurrence of a vacancy in the office of chairman, he shall succeed to the office of chairman. The secretary shall serve for three years.

\section{Article VI. Steering Committee}

Sec. 1. Composition. There shall be a Steering Committee consisting of the officers of the Section, the last retiring chairman, and six appointed members. The chairman of the Section shall serve as chairman of the Steering Committee. The appointments shall be made by the chairman.

Sec. 2. Terms of Office. The appointed members serve for three years. The initial members of the committee shall be appointed for terms expiring in different years. Sub- sequently two new members will be appointed each year.

Sec. 3. Powers and Duties. The Steering Committee shall aid the chairman in the development of the activities of the Section.

Sec. 4. Quorum. A majority of the members shall constitute a quorum of the Steering Committee.

\section{Article VII. Committees}

Sec. 1. Authorization. Committees of the Section as a whole shall be authorized by action of the chairman after consultation with the Steering Committee, but establishment shall not require action by the Steering Committee.

Sec. 2. Standing Committees. Standing committees may be established to consider matters of the Section that require continuity of attention by the members. When such a committee is established, its function, name, and size shall be determined. Unless otherwise approved by the Steering Committee, members of standing committees shall be appointed for terms of three years, and may be reappointed for a second but not a third consecutive term; in no case shall a person serve on a committee for more than six consecutive years. Appointments shall be made in such a manner as to provide continuity in membership.

Sec. 3. Appointment. The vice-chairman (chairman elect) of the Section shall appoint committee members to fill the vacancies due to occur during his term as chairman; he may name the chairman of each committee or request the committee to elect its own chairman. Special appointments to fill vacancies on committees may be made by the chairman.

Sec. 4. Discontinuance. A committee may be discontinued by the chairman of the Section with the approval of the Steering Committee.

Article VIII. Nominations and Elections

Candidates for elective office in the Section shall be presented by the Nominating 
Committee, appointed by the chairman for a one-year term. Other nominations may be submitted in writing by any ten members and shall be filed with the secretary. Any such nominations shall be included in the official ballot. No candidate shall be presented who has not consented in writing to his candidacy. Elections shall be conducted by mail ballot. The candidate receiving the largest number of votes shall be regarded as elected.

\section{Article IX. Vacancies}

Sec. 1. Chairman. If the offices of both chairman and vice-chairman become vacant within the same year, the Steering Committee shall designate one of its members to act as chairman until a chairman is duly elected. At the next election, two candidates shall be elected, one to take the office of the chairman immediately and to serve for one year, the other to serve as vice-chairman (chairman elect).

Sec. 2. Vice-Chairman. If the office of vice-chairman becomes vacant, two candidates shall be elected at the next election, one to take the office of chairman immedi- ately and to serve for one year, the other to serve as vice-chairman (chairman elect).

Sec. 3. Steering Committee. If an appointed member of the Steering Committee resigns, the chairman shall appoint a successor to complete the unexpired term, the appointment being subject to the approval of the rest of the committee.

Sec. 4. Secretary. If the office of secretary becomes vacant, a secretary shall be elected at the next election for a three-year term. A member of the Steering Committee shall be appointed by the chairman to serve as interim secretary until the election has taken place.

\section{Article X. Amendments}

Sec. 1. Proposals. Amendments to the Bylaws may be proposed by any committee of the Section or by petition signed by ten members of the Section. Proposed amendments shall be presented in writing to the chairman.

Sec. 2. Voting. The Bylaws may be amended by a two-thirds vote of the members present and voting at any given meeting of the Section.

\section{Junior College Book List}

James W. Pirie, librarian at the Charles Stewart Mott library in Flint, Mich., has accepted appointment as editor of the Junior College Book List, planned for publication by the American Library Association. The publication, when completed, will include fifteen thousand titles selected for the liberal arts program of junior colleges.

\section{ACRL Grants Program}

AN ADDITIONAL GRANT of $\$ 25,000$ has been received from the U.S. Steel Foundation for the 1965/66 program, for distribution to emerging institutions of the Southern states. Eligible institutions have been contacted by the ACRL Committee on Grants. Announcements of institutions receiving grants will be made in CRL, January 1965 (See also CRL, September 1965, p. 443) 


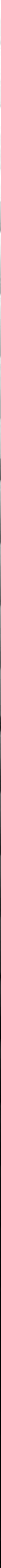




\section{At last.}
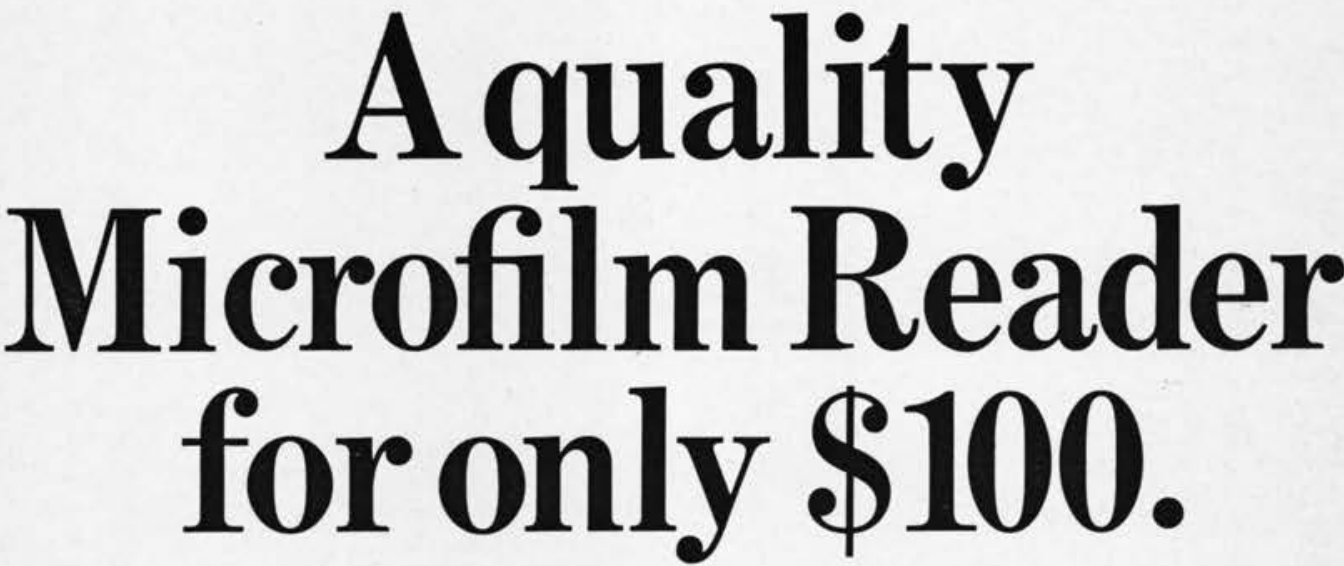

We've been in a ridiculous position for years.

Many librarians are eager to build a microfilm collection. And we're the largest supplier of microfilm copies of everything from doctoral dissertations to rare out-ofprint books.

Up until now, many librarians could not begin building a microfilm collection simply because they could not afford a good microfilm reader, costing $\$ 400$ or $\$ 500$.

For years we have been looking for a manufacturer who would produce a highquality microfilm reader at an economical price.

At last, we've found someone.

This machine not only matches the features of the expensive models, it has a few new ones of its own.

It's small-only $1^{\prime}$ deep by $1^{\prime}$ wide and only 2 ' high.

It's light-weighs only 13 pounds.

It runs cool-operates at $140^{\circ}$ without a fan.

It can be used in a brightly lit room - adjusts to any lighting condition.

It's easy to use-comes with microfilm roll holder and a single control knob.

It reproduces a clear image-the screen is coated so there are no hot spots.
It's versatile-it accepts $35 \mathrm{~mm}$ and $16 \mathrm{~mm}$ roll film. An optional microfiche attachment makes it possible to view fiche, jackets and aperture cards.

Now you'll be able to greet us with a big smile the next time we contact you about starting your microfilm library.

\section{XEROX University Microfilms, Inc. \\ A SUBSIDIARY OF XEROX CORPORATION}

Clip coupon to order Microfilm Reader or to get more information.

Please send me __ Microfilm
Reader (s).
$\square$ My check is enclosed. $\square$ Bill me.
$\square$ Please send more information.
Send to: University Microfilms, Inc.
$313 \mathrm{~N}$. First Street, Ann Arbor, Mich.
NAME_
TITLE_
ADDRESS__




\section{News from the Field}

\section{ACQUISITIONS}

JACKSON LIBRARY of the graduate school of business, Stanford University, has been given a collection of American banking histories. These were collected by the late George V. Hutton, Jr., of Kingston, N.Y., and were presented to the library by Mrs. Hutton.

DoROTHX BENDIx, associate professor of library science at Drexel Institute would appreciate receiving copies of acquisition policies from any academic libraries that have prepared them.

The UNIVERSTTY of Houston has acquired a collection of nine hundred Latin American plays from Willis Knapp Jones of Miami University, Oxford, Ohio.

University of Houston recently acquired the Ballinger Mills collection of about five thousand volumes for its law library, the gift of Mr. Mills. The collection of early American state reports and English law of the eighteenth and nineteenth centuries was supplemented by the letterpress books for the law firm, dating from 1840 to 1907 .

\section{A WARDS, GRANTS, FELLOWSHIPS, SCHOLARSHIPS}

INDIANA UNIVERSTTY libraries announces the continuation of a program to give intensive instruction to prospective rare book librarians. Two fellows will be selected for a study program using the facilities and collections of the Lilly library. Fellows will remain in residence in Bloomington, Ind., from July 1, 1966 to June 30, 1967. Each will receive a stipend of $\$ 5,000$ for the twelve-month period. Applications must be received in Bloomington on or before March 15, 1966, and appointments will be made on or before May 1. Requests for application forms may be addressed to Cecil K. Byrd, Librarian, Indiana University, Bloomington, Ind. 47405.

The Francis A. Countway library has been given $\$ 5,000$ toward the Aesculapian reading room by the Executive Committee of the Harvard Aesculapian Club. Aesculapian members throughout the United States have contributed nearly $\$ 132,000$ of a pro- jected $\$ 163,000$ needed to endow and equip the room.

The Bibliographical Society (London) has awarded its Gold Medal posthumously to William Alexander Jackson, former librarian of Harvard University's Houghton library of rare books and manuscripts.

WASHINGTON UNIVERSITY school of medicine has been granted funds for training biomedical librarians in computer technology and applications to biomedical literature, contingent upon passage of the budget by Congress. The grant by the National Library of Medicine will start on January 1, 1966, and continues for five years. Three students a year will be enrolled, and will receive a stipend of $\$ 5,500$ per year. Irwin $\mathrm{H}$. Pizer, during the planning and recruiting stage, will be half-time director while he is finishing his course work at the University toward the $\mathrm{PhD}$ in medical history. Mr. Pizer developed the computer-based serial system at Washington, and is now librarian of the Upstate Medical Center library, State University of New York, Syracuse.

Creighton University school of medicine has been granted $\$ 45,000$ by the John and Mary R. Markle Foundation for expansion of library holdings, which will be used to purchase back issues of scientific journals.

The Library Technology Project has been granted $\$ 15,000$ for the detailed planning of a three-volume manual on the preservation and restoration of books and other library materials by the Council on Library Resources. One volume is envisioned as dealing with the care and repair of ordinary volumes, a second volume devoted to rare books, and the third volume to conservation of other types of materials collected by libraries. Planning is expected to require a year.

A GRANT OF $\$ 7,931$ To $A L A$ to forward completion of its Catalog Code project was made by the Council on Library Resources. The Code is expected to be ready for publication in December.

The J. Morris Jones-World Book Encyclopedia-ALA Goals Award for 1966/67 has been announced by the Executive Board of ALA. It is available in support of 
programs which implement the ALA Goals for Action, to all units of ALA including chapters, for amounts up to the total of $\$ 25,000$ for the year. Applications are invited.

SCHOLARSHIPS IN SPECIAL LIBRARIANSHIP are offered for $1966 / 67$ by the Special Libraries Association, for graduate study at an accredited library school. Application forms may be obtained from the Special Libraries Association, 31 East 10th St., New York 10003, and must be received by the Scholarship and Student Loan Fund Committee at the above address by Feb. 1, 1966.

The American Standards Association has received $\$ 2,130$ toward support of a meeting at UNESCO headquarters in Paris in November to discuss international standardization of library statistics, from the Council on Library Resources.

\section{BUILDINGS}

Occupancy of the new library at Southern Colorado State College is planned for Christmas-vacationtime this year.

WASHINGTON UNIVERSITY has named an ad hoc committee for planning a new medical library building. The committee will probably continue to exist as a group to provide advice and counsel to the architects; Robert B. Austin, formerly deputy librarian, has agreed to act as consultant for the new building.

New York UnIVERSITY at Washington Square will break ground for a new $\$ 17$,500,000 library building next year. A test wall, some 30 feet wide by 40 feet high, was erected at the proposed site of the new building this autumn. The new structure will have space for two million volumes and seating for thirty-five hundred students.

Roberts Wesleyan College's new library was opened for service on May 13, and dedicated on Oct. 10. The North Chili, N.Y., college library will seat three hundred fifty and accommodates one hundred thousand volumes.

ADELPHI UNIVERSITY has a new two-story library building to house one hundred seventy-five thousand volumes and seat four hundred fifty readers.

Hofstra UnIversity's new library building will be a ten-story stack tower flanked at its base by interlocking pavillions housing catalog room, circulation desk, reference and periodical rooms, staff and technical processing areas. The library site is a sunken court about five feet below ground level. Stacks will house the present collection of four hundred thousand volumes with expansion space for twice that number; there will be seating provision for twelve hundred persons. The new library on the old (South) campus will be connected with a projected student center on the new (North) campus by a covered double-cantilever footbridge spanning Hempstead Turnpike.

The Randolph-Macon Woman's ColLEGE library in Lynchburg, Va., is in process of a $\$ 1,098,000$ expansion and renovation program. Contracts will be let in December for increasing book capacity to two hundred thousand volumes, and provide seating for half the student body.

A new Eastern Washington State College library is expected to cost more than $\$ 2,000,000$; bids were opened in August by the State Education Department.

The University of Houston began construction of an addition to the M. D. Anderson memorial library in July. The new addition, at a cost of some $\$ 3,300,000$, is expected to provide space for almost one million volumes and two thousand student seats including 404 graduate study carrels. The 126,000 sq. $\mathrm{ft}$. addition is planned for completion by early 1967 .

\section{MEETINGS, SEMINARS, WORKSHOPS}

A LIBRARY-COLLEGE WORKSHOP at Jamestown (N.D.) College is being planned for Dec. 18-21. The invitational conference will emphasize preparation of a statement of an ideal design for a library-college, in moderate detail.

Drexel Institute of Technology's graduate school of library science is offering a seminar in search strategy during the fall, winter, and spring quarters of this academic year. The course, surveying the field of information science, will be directed by Mrs. Claire K. Schultz.

The Jewish Library Association in cooperation with Drexel Institute of Technology graduate school of library science, is sponsoring a seminar on synagogue librarianship starting Oct. 26, and continuing for six consecutive Tuesday evenings. 
A COMPROMISE version of the Higher Education Act of 1965 (HR 9567) passed both Houses of Congress on Oct. 20, and is now awaiting President Johnson's signature. However, no funds were appropriated to implement Title II, providing for library programs. Hopefully, funds will be appropriated early in 1966 . For a copy of the conference report (House Report 1178) on the Higher Education Act, write to the House Document Room, U.S. Capitol.

\section{MISCELLANY}

Hoover Institution of Stanford University has established a project for cataloging by computer the material garnered from the late Herbert Hoover's files of the American Relief Administration. The project uses keyword classifications and is in charge of Mrs. Rita Campbell; at present it is "holding for funds."

The FIRST SIX volumes (1958-64) of the Index to Periodical Articles Related to Law have been cumulated and bound and is now available to subscribers for $\$ 15$; to nonsubscribers or subscribers beginning with volume 8 for $\$ 25$. The cumulation includes an author index, a subject index and a list of all periodicals indexed. It is available from Stanford University Law Library, Stanford, Calif. 94305.

LIBRARY OF CONGRESS ClASSIFICATION SCHEDULES, Subject Headings Used in the Dictionary Catalogs of the Library of Congress, and its supplements, and L.C. Classification-Additions and Changes will be distributed by the Library of Congress' card division beginning Nov. 1. Orders after that date should be addressed to the Card Division, Library of Congress, Building 159, Navy Yard Annex, Washington, D.C. 20541. Subscriptions currently in effect will continue in force until they expire.

Florida State University's library school is making a study of the feasibility of centralized record systems in Florida's junior college libraries. The study will deal with the practicality of preparing junior college records with the aid of data processing equipment, and will involve nineteen colleges.

A REVISED EDITION of National Inventory of Library Needs is now available from ALA for $\$ 2$ per copy.
A NINETEEN PAGE AUTHOR AND TITLE INDEX to the published volumes of Flügge Handbuch der Physik has been compiled by the Lincoln Laboratory library, M.I.T., Lexington, Mass. 02173. Requests for the index should be sent to Loyd Rathbun at the above address.

Montana State College, Bozeman, changed its name to Montana State University at Bozeman on July 1.

State University of New York has announced a library cataloging project to correlate resources throughout its fifty-eight member colleges and centers. The Upstate Medical Center library at Syracuse has been awarded $\$ 16,000$ to finance the first phase of cataloging. Irwin H. Pizer and Terrence J. Hoverter will direct the project, the compilation of a union list of periodicals and other current materials received each year by more than half of the colleges and centers. This will enable the university to determine what new resources are needed, and will clear the way for weeding of incomplete collections and for regrouping holdings. The initial phase is expected to include publication by February of a 350page checking list of twelve thousand titles. The project looks toward doubling of library holdings by 1970, and a system of interlibrary loans.

The UNIVERSITY of Houston library has released a catalog of its W. B. Bates collection of Texana and Western Americana. Copies are available from the library.

Abstracting Services in Science, Technology, Medicine, Agriculture, Social Sciences, and Humanities (The Hague: International Federation for Documentation, 1965) is FID publication 372 ; viii +320 p. The list was published in August and provides detailed information, with particular attention to sub-editions, on abstracts journals and card services. It is available (from the publisher) for 25 Dutch guilders-approximately $\$ 7$.

ACRL Membership on September 30, 1965 was 9,497 . Membership on October 30,1964 was 8,599 . Section and Subsection membership information will be published in the January issue. 


\section{Additional ACRL, Section \& Subsection Appointments}

The ACRL Committee on Appointments (1966) and Nominations (1967) includes G. Flint Purdy, chairman; Charles M. Adams, University of North Carolina, Greensboro; Miss Marion B. Grady, Ball State University; John F. Harvey, Drexel Institute of Technology; J. Elias Jones, Drake University; Samuel F. Lewis, University of Wisconsin Center System; William V. Nash, University of Utah; and Kathryn R. Renfro, University of Nebraska.

The Local Arrangements-1966 New York Conference Committee is chaired by Morris A. Gelfand, Queens College; Humphrey G. Bousfield, Brooklyn College; Ben C. Bowman, University of Vermont (librarian-designate of Hunter College); Mother Mary de Montfort, College of New Rochelle; Rice Estes, Pratt Institute; D. Nora Gallagher, Adelphi University; Esther Greene, Bernard College; Joseph T. Hart, Fordham University; Bernard Kreissman, City College of New York; Ellsworth G. Mason, Hofstra University; Roscoe Rouse, State University of New York, Stony Brook; and Brother Alexander F. Thomas, Iona College, are committee members.

Membership Committee's Junior College Libraries Section representative is Betty J. Harrison, Marshalltown (Iowa) Community College. Helen Paragamian is a member of the ACRL National Library Week Committee. Gustave A. Harrer, Boston University; and Archie L. McNeal, University of Miami, are members of the Ad Hoc Committee on Research. Harriett Genung, Mount San Antonio College, Walnut, Calif., is a member of the Standards Committee and E. Walfred Erickson was reappointed to the committee.

The Program Committee, 1966 New York Conference, will have Helen M. Brown as chairman; Morris A. Gelfand, and Eileen Thornton, Oberlin College, as members.

Foster E. Mohrhardt, National Agricultural Library, has accepted reappointment as ACRL representative to the American Association for the Advancement of Science.

The College Libraries Section Ad Hoc Committee on Community Use of Academic Libraries includes Barbara LaMont. The Section's Committee on Non-Western Resources numbers Evan Ira Farber among its members; Anne C. Edmonds, Mount Holyoke College, is this year's chairman. The Nominating Committee for the section is chaired by Roger C. Greer, State University of New York at Pots- dam; H. Joanne Harrar, Luella R. Pollock, James H. Rogers, and Elizabeth Simkins are committee members.

The Junior College Libraries Section Standards and Criteria Committee has as a member Elizabeth A. Martin.

The Rare Books Section Committee on Local Arrangements Chairman is J. Melvin Edelstein, New York University; Herbert T. Fuller Cahoon is a committee member. Chairman of the section Nominating Committee is Newton F. McKeon, Jr., Amherst College; committee members are Donald B. Engley, and Denton H. Wilcox. The Program Committee Chairman, 1966 New York Conference, is Marcus A. McCorison, American Antiquarian Society, and Edwin Wolf, II, is a committee member.

The Nominating Committee for the Subject Specialists Section includes Andrew Turchyn, Indiana University, chairman; Janet Louise Markel and Helen M. Nebenthau as members. The Agriculture and Biological Sciences Subsection Nominating Committee Chairman is John H. Moriarty, Purdue University; committee members include Robert W. Gerhardt and Mrs. Iola R. Stoehlein.

Mrs. Kathryn Blackwell was elected vice chairman and chairman-elect of the Art Subsection; Mrs. Marie D. Peck, St. Paul public library, was elected secretary of the subsection.

The Law and Political Science Subsection Nominating Committee this year includes Chairman Gerritt E. Fieldstra, Anthony P. Grech, and Howard Haycraft. The subsection's Ad Hoc Planning Committee is chaired by Robert C. Miller, Marquette University; members are Janet M. Rigney and Jane Wilson. The Nominating Committee of the Slavic and East European Subsection Chairman is Mrs. Elizabeth Nebehay, United Nations Dag Hammerskjöld library; committee members include S. L. Jackson and Mrs. Helene Reshetar.

The University Libraries Section's Ad Hoc Committee on Academic Status has new members Leslie W. Dunlap, Carl W. Hintz, and W. Porter Kellam; Lewis C. Branscomb, Ohio State University, is again chairman. Nominating Committee for the section includes Marjorie E. Karlson, Washington University, St. Louis, as chairman; John P. McDonald and Joseph H. Reason. New members of the ULS Research and Development Committee are Earl Farley, David W. Heron, and George Piternick; Gustave A. Harrer is chairman again this year. Newly appointed members of the Steering Committee are Ben C. Bowman and Basil StuartStubbs. New members of the Urban University Libraries Committee, of which Lorena Garloch remains as chairman are Mark M. Gormley, Edward G. Holley, David C. Weber, and William L. Williamson. 


\section{Personnel}

\section{APPOINTMENTS}

HarrietT Dyer Adams has been appointed assistant librarian of the graduate school of public affairs, State University of New York, Albany.

JAmes A. Allen is director of Larson library, Little Rock (Ark.) University.

Mrs. Marlene Allison is an assistant librarian in technical services at State University of New York, Albany.

ISABELLE T. ÁNDERSON became librarian of the Barrow Neurological Institute of St. Joseph's hospital, Phoenix, Ariz., on Sept. 1.

SUSAN APLIN joined the reference staff of University of California library, Santa Barbara on Sept. 1.

Mrs. BARBARA Aro is now binding librarian, Washington University, St. Louis.

Mrs. Martha Avery has been appointed to the serials department staff of the University of California library, Berkeley.

Frances Banko is now a member of the library acquisitions staff at City College, New York.

RUDOLF BART has joined the staff of the UCLA library to catalog Near Eastern publications.

Victor A. BASILE is the new chemistry librarian at Indiana University.

RoDMAN BASSEIN is the new serials cataloger in Rush Rhees library, University of Rochester.

Mrs. Alice Bauer assumed the duties of head of the catalog department in the University of Cincinnati library on Sept. 1.

Gladys H. Bean has been appointed humanities librarian of University of Arizona, Tucson and joined the staff on Sept. 1.

AnN BRistow Beltan is now assistant documents librarian at Indiana University.

Georgiane K. Bentzlen is librarian of the Marshfield-Wood County center of the University of Wisconsin in Marshfield.

WILLIAM BERGERON has been appointed administrative intern in the UCLA librarian's office.

Mrs. Regina Berneis has joined the staff of Western Michigan University's department of librarianship laboratory library, Kalamazoo.
Mrs. Sue BielawsKr is chief bibliographer in the Indiana University libraries order department.

NEIL S. BOARDMAN is administrative assistant to the directors of libraries, Indiana University.

LORISE BOGER is now chief reference librarian of West Virginia University, Morgantown.

Mrller Boord has been appointed librarian of Randolph-Macon Woman's College, Lynchburg, Va.

DAviD Briggs joined the University of California, Santa Barbara, reference staff in August.

Mrs. Jeanne Briner has accepted the position of bibliographer in University of Arizona library, Tucson.

Mrs. Marjorie Ferrier Brister is now serials librarian at Montana State University, Bozeman.

EDWARD H. BroadHEad is the new director of Southern Colorado State College libraries.

Mrs. Carlene Brown is a new member of the library acquisitions department staff at University of California, Berkeley.

Harry W. Bruton is the new head of the catalog department in Southern Colorado State College libraries.

Mrs. Barbara D. Bryan has been named assistant director of libraries at Fairfield University (Conn.).

LAURETTA BUCK is assistant serials cataloger in Southern Illinois University library, Carbondale.

Cynda Lou Buxton became business administration librarian in University of Denver in September.

Margaret Capron became a member of the library staff at University of California, Santa Barbara, in the serials and cataloging departments.

Kelley Cartwright has joined the staff of the Institute of Library Research, University of California, Berkeley.

Terrence W. Cassidey is assistant order librarian at Indiana University.

Mrs. Geraldine Cohen became research assistant in machine methods at Washington University school of medicine library, St. Louis, in September. 
EdWARD Collins has joined the catalog staff of Western Michigan University, Kalamazoo.

Mrs. Helga Cope has joined the central serials record division of the City College library, New York.

Mrs. Mina Crais is cataloger at Sibley music library, Eastman school of music, University of Rochester.

Alice Creighton is history of medicine librarian, University of Rochester school of medicine and dentistry.

Thomas L. Crystal, Jr., is the new Latin American bibliographer in the resources and development program at Stanford University libraries.

Mrs. Gerald F. Dingman is now assistant librarian of Bates College, Lewiston, Me.

SANFord Dorbin was named to the acquisitions staff of University of California, Santa Barbara library.

Eleanore C. Dowling has been appointed music cataloger, Washington University libraries, St. Louis.

RAY Drolsom is now serving as catalog librarian in Joint University libraries, Nashville.

Norman Dudley has been named head of the acquisitions department in UCLA library.

Karin A. ECKelmeyer is a new member of the catalog division, Stanford University libraries.

Thomas Ertingon has become a library cataloger at the City College, New York.

Jim R. Elkouri has joined the catalog division of Stanford University libraries.

C. JoHn Eschelbach has joined the staff of Foothills College library, Los Altos Hills, Calif.

RUSSEL Evans is assistant cataloger at Wisconsin State University library, Lacrosse.

Stephen S. A. Faunce accepted the position of assistant to the librarian, Washington University school of medicine, St. Louis, and began work on Sept. 20.

Gilbert G. Frtes became librarian at Northeastern State College, Tahlequah, Okla., on Sept. 21.

RICHARD Fredell has been named assistant to the director, Washington University libraries, St. Louis.
Rudolph H. GJelsness joined the staff of University of Arizona library, Tucson, as chief special collections librarian.

DoRothy Graham has returned to UCLA library and will be in the catalog department.

Elizabeth Graves became librarian of the Rotch library of architecture and planning on Oct. 25.

Robert W. Greenwood is now assistant director for technical services and head of the acquisitions department of Tulane University library, New Orleans.

ANTHONY HaLl has been named director of library systems analysis and development in UCLA library.

Frederick A. H. Hall was named bibliographer for Latin American and Iberian history and literature in Newberry library, Chicago; he assumed his duties on July 16.

Amanda Harmon has joined the reference department staff of Rush Rhees library, University of Rochester.

Helen Healy has joined the library staff of the Educational Resources Center, Western Michigan University, Kalamazoo.

Martin Helgeson is now a member of the library's catalog division, City College, New York.

Carolyn Hesselmeyer joined the University of South Florida staff on July 1 as assistant reference librarian.

Mrs. Lutie Higley is the new chief public services librarian of University of Arizona, Tucson.

CARL W. Hintz, University of Oregon librarian, assumed the additional duties of director of libraries, Oregon State System of Higher Education, on July 1.

Mrs. Margaret C. Hout is a new member of the technical services library staff at State University of New York at Albany.

JOSEPH HowARD has been named chief of the catalog department, Washington University libraries, St. Louis.

Tsai Hsu has been named reference librarian at Montana State University, Bozeman.

Chung-Kai Huang is the Asian librarian, Rush Rhees library, University of Rochester.

WASYL Huculak has accepted the position of assistant cataloger on the library staff of Southern Illinois University, Carbondale. 
Margaret E. Hughes has been named head librarian of the University of Oregon medical school.

Philip IMroth became a cataloger in the University of Denver libraries last spring.

RICHARD M. Johnson is the librarian of the Manitowoc County center, University of Wisconsin.

RoBert D. Johnson has joined the staff of Foothill College library, Los Altos Hills, Calif.

Elaine Maria Keebler is mathematicsastronomy-physics librarian of Indiana University.

J. Gordon Kenefick is now associate librarian, Yale University.

SHAKÉ KeshKeKIAN is newly appointed to the catalog division of Stanford University libraries.

Mrs. Priscilla Kirshbaum joined the reference staff of University of Denver libraries in September.

William H. KNeEdler has been appointed assistant librarian in charge of acquisitions, New York City Community College.

Bertram H. KNouse has been named assistant librarian, State University College, Geneseo, N.Y.

EVELYN M. KOcher is chief catalog librarian of West Virginia University, Morgantown.

AKE I. KoEL has been appointed head of technical services in Hamilton College library, Clinton, N.Y.

ElFRIEDA LANG was appointed curator of manuscripts at Lilly library, Indiana University, effective July 1 .

ANNETTE LEE is now gifts librarian of Indiana University.

JUDITH LEONDAR has been named to the staff of the newly-established Bureau of Information Sciences Research at Rutgers.

SAMUEL F. LewIS is the new associate director of the University of Wisconsin Center System libraries.

Thompson M. LrTtre becomes associate director of library services, Hofstra University, Hempstead, L.I., N.Y., on Nov. 1.

JoHn B. Lru has been appointed Oriental studies librarian of University of Arizona, Tucson.
JOSEPH D. LOwE is the new librarian in the Far East library, University of Washington, Seattle.

MatT P. Lowman, II, has been named curator of rare books and assistant head of special collections at Newberry library, Chicago.

CAMden McConnell has been in charge of reserve book service at University of California, Santa Barbara, since July 12.

Susan McEwan has accepted the position of assistant cataloger in University of South Florida library, effective Sept. 7.

Carolyn McMirlen has been named serials librarian at Michigan State University, East Lansing.

Mrs. Bertha Makow has joined the staff of the UCLA biomedical library.

Mrs. Sherrill Mann was appointed to the catalog staff of the University of California library, Santa Barbara, on July 11.

Carlos E. Marreno is assistant in the education-psychology division library, Southern Illinois University, Carbondale.

Virginia Lowell Mauck has been named assistant curator of manuscripts, Lilly library, Indiana University.

Robert W. Mautner is chief science librarian, University of Arizona, Tucson.

Mrs. Sylvia Merritt is newly appointed to the circulation and reference staffs of UCLA law library.

Roy M. Mersky on Sept. I assumed the position of law professor and director of research, which includes responsibility of the law library, at University of Texas, Austin.

Agnes Metzler is now administrative assistant to the director, Tulane University library, New Orleans.

JAMES T. Mrchna has been named assistant to the director, Center System libraries, University of Wisconsin.

Paul Miles will serve during the coming year as director of a library liaison center in Santiago, Chile, to coordinate many of the functions of the cooperative program of the universities of Chile and California.

Theodora Mills is now Slavic cataloger in Rush Rhees library, University of Rochester.

Myrna Jean Morton has joined the acquisitions department staff at Ohio Wes- 
leyan University library.

Robert F. MunN, director of libraries, West Virginia University, Morgantown, has been named assistant provost of the university. $\mathrm{He}$ will continue to serve as library director.

David Nevin is the new chief of the audio-visual department, Washington University libraries, St. Louis.

Elmer J. O'Brien has been named assistant librarian, Garrett Theological Seminary, Evanston, Ill.

LE Roy D. Ortopan has been named chief of cataloging in University of Wisconsin library on Sept. 1.

WILliam Osuga has been made head of the interlibrary loans section of the UCLA library's reference department.

Thomas F. Parker has joined the UCLA library's reference department staff.

Huibert Paul accepted appointment effective Aug. 16 as acquisition librarian, University of Oregon.

Mary Jo Peterschmid has been appointed to the undergraduate library staff of the University of Washington, Seattle.

David PICca joined the acquisitions staff of University of California, Santa Barbara library, on June 14.

Donald M. Powell has been appointed assistant university librarian of University of Arizona, Tucson.

Delores ANn Pritchard has returned to the library staff of the University of California, Santa Barbara, and is assigned to the reference department.

Louise G. Pritchard joined the staff of the University of Arizona, Tucson, as interlibrary loan librarian, on Aug. 1.

Mrs. Ellen PUgH is associate cataloger for foreign monographs in Rush Rhees library, University of Rochester.

ARmando RE is the new assistant librarian for technical services in the State College at Salem (Mass).

Arne Richards is now documents librarian, Kansas State University, Manhat$\tan$.

Olive L. Roberts is now director of Norton library, Louisiana College, Pineville.

Katherine Ryan began work in Foothill College library, Los Altos Hills, Calif., in September.
Mrs. Lucy Salvia joined the catalog department of University of California library, Santa Barbara, in August.

CATHerine Nicholson Schuicting has joined the reference department staff of Ohio Wesleyan University library.

JANET F. SCHMIDT has been named librarian of the Marathon County center of University of Wisconsin, Wausau.

Monica M. Schnemer has been appointed librarian of the Fox Valley center, University of Wisconsin, Menasha.

ROGER E. SCHWENN is now director of the Center System libraries, University of Wisconsin, Madison.

Ada M. Seltzer joined the staff of the University of South Florida on Aug. 1, as assistant reference librarian.

Mrs. Janice H. Shawl has been appointed to the staff of the UCLA library's catalog department.

Ralph M. Shoffner has been named to the staff of the Institute of Library Research at University of California, Berkeley.

Elizabeth A. Shoughro has been named assistant director for reader services and science librarian, Tulane University, New Orleans.

Mrs. Mildred Srmmons has been appointed elementary school librarian in the Peabody demonstration school, Nashville.

DAVID R. SMITH is a newly-appointed reference librarian at UCLA.

JoHN B. Sмrтt was named assistant law librarian at Columbia University, effective July 1.

Kraus Speer has joined the staff of Sibley music library of Eastman school of music, University of Rochester, and will be working with the rare book collection and assisting graduate students.

Al SQuillante assumed his duties as law librarian of the University of Denver in September.

JANE STEvens is the new head of the order department, Tulane University library, New Orleans.

Mrs. Tamara Strubel has joined the cataloging staff of Rush Rhees library, University of Rochester.

George R. Swanson has joined the reference staff of Montana State University library, Bozeman. 
JANice L. Thompson is map librarian at Southern Illinois University, Carbondale.

AnN Tupper has joined the technical services staff of State University of New York at Albany, as assistant librarian.

ANTHONY H. VAUGHAN is a new member of the reference staff, University of California library, Santa Barbara.

Mrs. Sally S. WaCH was appointed on Sept. 1 to the staff of the biology library, University of California, Berkeley.

Eleanor Wedge is the new fine arts librarian at Indiana University.

James M. Whitehead is the new science librarian, University of Colorado, Boulder. Mrs. Alice Wilkins joined the staff of Joint University libraries, Nashville, this autumn, as catalog librarian.

BERNARD WILSON became head of the processing department, Newberry library, Chicago, in July.

BEtTy RUth WILson is the new assistant

B \& T's office and warehouse at Hillside, N.J.

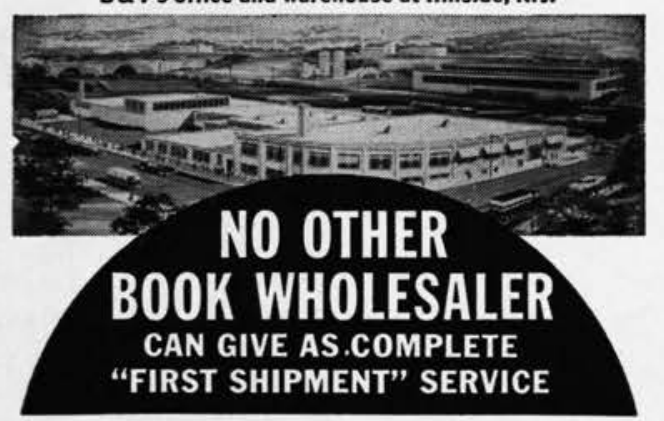

THE BAKER \& TAYLOR CO. Oldest and Largest Exclusive Book Wholesaler HILLSIDE NEW JERSEY MIDWEST AND SOUTHERN DIVISION

Both B \& $T$ warehouses stock, for immediate shipment, larger numbers of book titles from more publishers than any other book wholesaler.

Prompt filling of "shorts". Complete

reporting on "shorts". Competitive discounts. Details

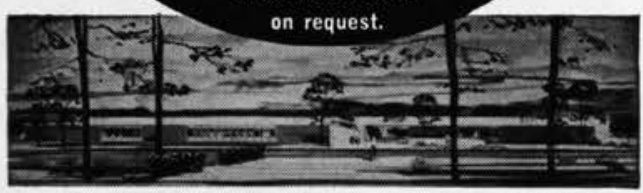

B \& T's new Midwest and Southern Division, Momence, III. cataloger in the libraries of Southern Illinois University, Carbondale.

Mrs. Eva B. Winter has been appointed serials librarian of Pennsylvania Military College, Chester.

AlLEN WYNNE became assistant acquisitions librarian at Colorado State University on July 1.

Wendell A. Yeatts, Jr., has been appointed senior assistant librarian and head of the data processing department of the University of Missouri library.

Mrs. Martha Young, formerly of the H. W. Wilson Company, is now a library cataloger at the City College, New York.

\section{NECROLOGY}

Mrs. Fannie Hendrie, staff member of the library for 36 years at Drexel Institute of Technology, died on Sept. 2.

Mortimer Taube, chairman of the board of Documentation, Inc., Bethesda, Md., died on Sept. 3.

\section{RETIREMENTS}

ANN BINFIELD, after 19 years of service to Pueblo College and its successor Southern Colorado State College, retired as college librarian at the end of June.

William H. Carlson retired as librarian of Oregon State University and director of libraries, Oregon State System of Higher Education, at the end of June.

Mrs. Mabel J. ErLer retired Aug. 1 as head of the order department, Newberry library, Chicago, after 37 years of service.

Ruth Grierson retired this past summer as librarian of Lycoming College, Williamsport, $\mathrm{Pa}$.

Bertha Hallam has become librarian emeritus after heading the library of University of Oregon medical school for the past 46 years.

Mrs. Adelheid Gertrud Ladewig, head of technical services in Hamilton College library, Clinton, N.Y., for the past 19 years, retired this summer.

DoRIS REED, curator of manuscripts at Lilly library, Indiana University, retired on June 30.

Francis Wright retired on Aug. 31 from her position as assistant director of libraries at Drexel Institute of Technology. 


\section{They Say About}

\section{CHOICE: books for college libraries...}

"A study of the first five numbers of CHOICE shows clearly that the annotations are of a high grade-critical, informative, and authoritative. A special effort has been made, where feasible, to judge a title in relation to the other literature in the same field. This feature alone is valuable to the librarian, for it enables him to review quickly his own holdings. ... The first five issues contain a series of informative editorials on the whole problem of current book selection in the college library as well as an excellent discussion of available tools for assessing one's holdings. ... . An indispensably useful current book selection guide for college libraries. The more limited the library budget, the more necessary is CHOICE."

"A Splendid Choice" by Rev. Francis A. Small, in Catholic Library World, Vol. 36, No. 3, November, 1964.

"College libraries have desired and anticipated a publication which would continually and systematically update the Shaw list. For current publications this purpose has been admirably fulfilled by CHOICE. ... Although many of the titles reviewed in CHOICE are either upper division or graduate level and therefore not generally needed by the average junior college library, the writer has discovered through intensive use of this book selection tool that many of the titles reviewed are appropriate for junior college libraries. Therefore CHOICE was decided upon as the means by which to secure a sample of book titles to be tested for this study. Although this publication has been in existence less than one year at the time of the study, sixteen libraries indicated that it was either their first or second choice as a selection aid for current books. ... CHOICE received eleven first place votes as compared with nine first place votes for Library Journal."

\begin{abstract}
"Processing Center for California Junior College Libraries-A Preliminary Study" by Everett L. Moore, in Library Resources \& Technical Services, Vol. 9, No. 3, Summer, 1965.
\end{abstract}

"The creation and operation of a college library service center to act as the purchasing and cataloging agent for a number of small colleges in a given region would effect material savings and increase efficiency. Until such a service center is available, every Negro college library should be assured a subscription to CHOICE, a recently established reviewing journal prepared specifically for college librarians and faculty members."

The Predominantly Negro Colleges and Universities in Transition by Earl J. McGrath. Teachers College, Columbia University, 1965.

\section{ARE YOU A SUBSCRIBER?}

Order from ALA's Subscription Department, 50 E. Huron St., Chicago, III. 60611. $\$ 20.00$ yearly for initial subscription. Additional copies to the same address $\$ 10.00$. Single copies $\$ 2.00$. 